\title{
Invisible presence? Polish in Norwegian public spaces
}

\author{
Toril Opsahl ${ }^{1}$
}

\section{Overview}

Poles are by far the largest group of 'immigrants' to Norway represented by more than one hundred thousand individuals. Nevertheless, the presence of Polish has been at least until recently - somewhat hard to spot in public spaces. Polish presence in Norwegian broadcasting media is limited, and previous studies in educational settings have claimed that Polish pupils are overlooked in schools. So far, there are relatively few sociolinguistic studies of Poles in Norway. This chapter explores and reflects on the presence of Polish in public spaces in an area of the capital Oslo, drawing on parallel field observations from three women. To some extent, the data support an impression of invisibility. However, Polish presence is observed across several dimensions in public space (such as advertising billboards, construction sites and professional settings, e.g. in public hospitals). Parts of the observed Polish presence strengthens stereotypical images of Poles as one-dimensional (blue-collar) workers and professionals. Still, there is little doubt that there exist strong and multifaceted linguistic practices involving Polish in Oslo, but these practices seem to exist parallel to, and to a lesser degree intertwined with, Norwegian and other languages, in public spaces. The dominant language ideologies characteristic of Poland and Norway, respectively, raise questions of how the concept of national identity intersects with multilingualism, as well as to the relationship between cultural and linguistic identity. To the point where one may speak of individual multilingualism, it is in many ways protective of distinctive identities in this specific socio-historical setting. Identities associated with professional life are the most prominent traces of Polish in public spaces, alongside a potential consumer identity connected to market logic. The close connection between language and labour may at first glance be seen as a positive sign of empowerment of individuals. The presence of Polish is ambivalent, however, since the agency of individuals in terms of their daily use of language is challenged when the presence of Polish in public domains continues to feed and maintain stereotypical images of available identities, depending not only on a symbolic value but also on market economy. Methodological insights from the present study support the assumption that research on the relationship 
between multilingualism in public spaces and the empowerment of individuals needs to include and recognize individuals as interpretative subjects and agents.

\section{Poles in Norway}

According to Statistics Norway (SSB), immigrants from Poland make up the largest immigrant group in Norway, with 98,700 persons as per 1 January 2019 (SSB 2019). At this time the total number of immigrants was 765,100 , accounting for 14.4 per cent of the Norwegian population. The percentage is higher in urban areas, and 33.1 per cent of the capital Oslo's entire population have a migrant background. SSB defines immigrants as 'persons born abroad of two foreign-born parents and four foreignborn grandparents'. Norwegian-born to immigrant parents account for 3.4 per cent of the population. Among these, we find an additional number of 13,300 persons with Polish background. Statistics and the cover term 'immigrant' do not tell us much about the people hidden behind the figures and percentages, but they do tell us that at least 112,000 individuals in Norway lead some sort of transnational lives with ties to Polish networks and communities. As noted by Obojska (2018), the recognition of interconnectivities across and beyond national boundaries in people's experiences is particularly relevant for Poles, due to their long immigration history, constituting one of the twenty largest diasporas in the world (83).

Polish immigration history in Norway started as early as the 1830s (Godzimirski 2011), but the numbers of Poles in Norway were relatively small through the following decades. A small number of Poles ended up in Norway after the turmoil following the Second World War, but what has been called the 'first phase' of modern PolishNorwegian migrant history did not take place until the 1980s. Approximately two thousand of the political refugees fleeing the martial law of the Jaruzelski regime ended up in Norway. Among them were many prominent intellectuals and artists, today well established within Norwegian society (Friberg and Golden 2014: 12). The second phase, according to Friberg and Golden, was a response to the economic challenges following the end of the communist era and the transition to market economy in the 1990s. A large group of Poles came to Norway for temporary work based on bilateral agreements. The Polish work force was especially connected to agriculture, establishing a stereotypical conception of Poles as being 'strawberry-pickers' supplementing their income with seasonal work abroad. The migration pattern characteristic of the 1990s is largely based on short-term stay and hence circular. Still, Poles made an imprint through the establishment both of more or less permanent professional and social networks, and of cross-cultural marriages and family reunions, as well as through receiving specialist work permits, especially within the healthcare sector (Friberg and Golden 2014: 13).

The third phase in the immigration history starts on 1 May 2004 with European Union (EU) enlargement and the implementation of European Economic Area (EEA) rules, resulting in radical changes of conditions for migration patterns between Poland and Norway. Over the next ten years, the number of Poles in Norway increased from around seven thousand to more than eighty thousand, representing the largest wave 
of migration to Norway through all times (Friberg and Golden 2014: 15). Since 2006, the growth of Polish labour immigrants to Norway has been accompanied by increased family-related immigration, and in 2007, the Poles became the largest immigrant group in Norway (Godzimirski 2011). There has been a shift from the 2004-typical 'lone man working in the construction sector sending money back to Poland' to trends of entire families moving and reuniting ten years later, also resulting in a more equal gender balance within the Polish immigrant population (Friberg and Golden 2014: 15). Slåke (2018) indicates that we now may be facing a fourth phase in the Polish-Norwegian immigration history since net immigration has decreased in the last few years, possibly as a response to a weaker Norwegian economy. Poland, on the other hand, has had an uninterrupted economic growth for the past 20 years (Slåke 2018: 15). Nevertheless, people from Poland still hold their position as the largest 'immigrant group' in Norway.

Despite this status, Poles in Norway have received relatively little sociolinguistic research attention. Within Norwegian SLA research, a rich tradition has grown for the use of written language corpora, also involving texts from Polish participants, carving way for Polish-Norwegian research cooperation (Golden and Tenfjord 2014; Golden, Jarvis and Tenfjord 2017). Among the existing studies of Polish users of Norwegian, many are thus devoted to their written language use and the acquisition of specific grammatical features such as the Norwegian tense system (Janik 2017) and spatial prepositions (Szymańska 2017). Some studies of spoken use of Norwegian and comparative Polish-Norwegian conversational studies exist as well. Horbowicz's studies (e.g. Horbowicz 2010) suggest that the Polish speakers of Norwegian fail to convey several interactive features by means of adequate structures, which may lead to them being perceived as impolite, aggressive or uninterested. Urbanik $(2017,2020)$ shows several discrepancies in the grammatical and pragmatic patterns of requests in Norwegian and Polish. The notion of conversational politeness, and thus of socially acceptable requests, differs between the two languages. Research on communication among Poles on Norwegian construction sites, such as the pioneering work performed by Kraft (2017), is of special relevance for this chapter. Kraft sheds light on how the stratification between Norwegian and Polish construction workers relates to the language policies, ideologies and practices on the construction sites. Of great relevance to this chapter is also Obojska's equally pioneering work on family language policy in Polish families in Oslo, with emphasis on young Poles' language practices and thoughts on language maintenance (Obojska 2017, 2018; Obojska and Purkarthofer 2018). Bygdås’s (2016) unpublished MA thesis on language choice and identity among Polish adolescents in Oslo should also be mentioned among the small but growing body of sociolinguistic studies on Polish presence in Norway.

\section{Background, motivation and research questions}

A notion of under-representation - or even absence - of Poles and Polish in Norwegian public space seems to be a recurring theme in existing studies from different fields. Berezkina's (2018) study of virtual Linguistic Landscapes (LLs) examines language policy on central state websites in Norway and shows how the official practice of 
promoting multilingualism is in decline, also influencing Polish presence. Berezkina has also performed a traditional LL study of Grønland, one of the most multicultural districts of Oslo, showing that the presence of - especially non-Western - migrant languages is limited and restricted to mostly hand-written, 'bottom-up', unofficial parts of the LL (Berezkina 2012). Among her data, only one example of the use of Polish is mentioned (Polish is one of eleven languages on an official poster from Oslo municipality about available Norwegian language classes). In her study of two major shopping streets in central Oslo, Stjernholm (2013) does not mention any Polish presence at all. Norwegian and English is dominant in her quantitative analysis, alongside some scattered instances of languages such as Italian, French, Spanish, Latin and Swedish (Stjernholm 2013: 81). Stjernholm comments on how 'the low value placed on immigrant languages appears to warrant their exclusion from these linguistic markets' (2013: 83). For Wærdahl (2016), the notion of invisibility turned out to be relevant both as a descriptive and an analytical point in their study of Polish children in Norwegian educational contexts. Information concerning language and cultural background of the Polish children was often missing. This made it difficult to access the children as a researcher, and 'they [i.e. the Polish children] seemed to be overlooked in school as well' (Wærdahl 2016: 95). They find that expectations of school and education are seldom articulated, and there are several examples of poor communication between schools and families, creating the risk of overlooking the social and academic challenges that Polish children face, because cultural differences and differences in pedagogical views are swept under the rug (2016: 102). Slåke (2018) conducted a series of searches in the Norwegian Broadcasting Corporation's (NRK's) internal databases, revealing that the broadcasts covering Poles and Poland have been few compared to the coverage of other nationalities. Slåke assumes further that this under-representation in the NRK's media coverage reflects public discourse in general. Golden and Opsahl (2019) show how the majority of written media's representation of Poles in Norway is one-dimensional, feeding a stereotypical image of a male work migrant often involved in shady business. In 2014, a national research campaign involved school children from all over Norway in the collection of slang and loan words, and while a myriad of languages and cultures were represented, hardly any examples from Polish were reported (Bjorvatn 2015: 45).

Over the last decades, the urban space has been an important focus of interest among Norwegian sociolinguistic researchers. The urban centres were postulated as impact sources for the emergence and spread of linguistic innovations leading to dialect levelling and regional dialects (e.g. Mæhlum 1998; Røyneland 2009). Urban areas have also received research attention as the locus of the emergence of so-called multiethnolectal speech styles (see, for instance, Aarsæther 2010; Opsahl 2009; Svendsen and Røyneland 2008). It is worth noticing that Polish is seldom mentioned among the languages contributing to a multiethnolectal feature pool in these studies. According to Barni and Bagna (2015: 9), the urban contexts represent the most interesting and significant sources for examining and interpreting linguistic dynamics. A city provides the sufficient space for languages to 'manifest their vitality as well as their visibility' (ibid.). Further, Barni and Bagna point to how big cities with a strong multiethnic component may be a place 'where collective and individual identities are 
able to express themselves, since spaces that are more open to creativity, change, and relations between social and linguistic groups are also more dynamic' (ibid.). The notion of 'invisibility' present in the literature review above makes it uncertain whether the Norwegian capital is a space where collective and/or individual identities are able to express themselves through linguistic resources associated with Polish. Moreover, the question remains as to what extent one may speak of empowerment for users of Polish-Norwegian multilingual repertoires in the Norwegian context.

The notion of invisibility also resonates well with my own impression during unsystematic field observations in Oslo during spring 2018, which triggered a curiosity towards the status of Polish presence in Norwegian public spaces. Hence, the overarching goal of the present contribution is to shed further sociolinguistic light on the largest group of so-called immigrants in Norway, with an emphasis on the interplay between the visibility of Polish presence in public spaces, and to what extent this specific case of multilingualism relates to the empowerment of individuals. What makes the encounter between Polish and Norwegian even more interesting, seen from a sociolinguistic perspective, are the contradictions regarding linguistic variation and diversity, and the prototypical attitudes thereof, in the two communities.

The research question discussed in this chapter is descriptive, asking in what ways Poles and Polish are visible and/or audible in public places in Oslo. During the search for possible explanations for the (lack of) Polish presence, questions of the relationship between cultural identity and linguistic identity are addressed. Is multilingualism protective of distinctive cultural identities or does it erode them? What does it mean for the agency of individual citizens in terms of their daily use of language? Last, but not least, the chapter discusses the relationship between multilingualism and empowerment of individuals. Empowerment may be seen in close relation to employment. Polish immigrants to Norway are not automatically included in official immigration policies (creating challenges in extracting data on Polish schoolchildren, as mentioned by Wærdahl (2016)). EEA supranational principles regulate Poles' movement and access to Norwegian labour markets, and Polish migrants are not automatically included in integration and language programmes (Iglicka, Gmaj and Wierzejski 2016). According to Iglicka, Gmaj and Wierzejski, 'their adaptation and migration decisions are therefore related heavily to their position at the labour market - their access to jobs and financial security' (2016: 129). Recent initiatives have been made, but until now few in-depth studies of the role of language and communication for an inclusive working life and the welfare for all citizens in Norway exist (Friberg, Dølvik and Eldrine 2013: 46; Opsahl et al. 2019). As pointed to by an anonymous reviewer, there is an important issue at stake here in twenty-first-century Europe, with Poles emerging as totemic for lowerwage manual labour, sometimes scapegoated by nationalist movements. The extent to which they are empowered, marginalized or visible is of great urgency.

\section{The notion of invisibility}

Shifting structures of power and asymmetrical relations render some types of practices and repertoires more legitimate, and therefore more visible (Kerfoot and Hyltenstam 
2017: 8). Securing control over defining what counts as legitimate language thus become an important means for securing access to power (Heller and Duchêne 2012: 5). The absence of languages in cities, shops, schools, offices, moving buses, beaches and cyber space - and so on and so forth - is thus important data to be studied, according to Shohamy and Gorter (2009: 2), especially in areas which are politically and socially contested. Silence is not the same as non-communication (Thurlow and Jaworski 2010). A growing body of empirical research recognizes notions of absence and silence as important aspects of discourse studies (Schröter and Taylor 2018). As pointed out by Wærdahl (2016), with reference to Leinonen and Toivanen (2014), the terms 'visible' and 'invisible' have been employed in the study of migrants and minorities for almost 50 years, especially among US scholars, often in connection with certain migrant groups' ability to 'melt' into mainstream society. European scholars have more often turned to concepts like ethnicity, nationality or culture when making distinctions between groups based on their supposed origin (Leinonen and Toivanen 2014: 161). One may easily resist the use of a concept like in/visibility because no human is invisible. However, a focus on in/visibility can help analyse 'how various processes of racialization and practices of 'othering' come about and manifest themselves in Nordic societies' (ibid.). Moreover, the 'immigrant' category traditionally has strong connotations to visible differences in Norway, with skin colour as a prominent factor (Berg 2008: 216; Guðjónsdóttir 2014). Gullestad's influential studies (e.g. Gullestad 2002) show how the term 'migrant' typically invokes images of persons with dark skin, often of a third-world origin, with values that differ from those of the Norwegian majority. This image may have shifted after the 2004 EU enlargement, but still seems to be of relevance. Guðjónsdóttir's (2014) work on Icelandic migrants in Norway in the aftermath of the 2008 economic crisis shows how the migrants themselves construct belonging through racialization:

Confronting the racial diversity of Oslo, the participants take a hegemonic position and judge who fits and who does not. In their narratives, the participants take part in constructing Norwegian society as 'white' with certain cultural (Christian) values and middle-class norms. Through these narratives, a space is carved out for the inclusion of 'white' Icelanders, while 'non-white' people are marked as nonNorwegian and not belonging to Norwegian society. (Guðjónsdóttir 2014: 180)

There seems to exist a hierarchy of national 'whiteness' as well, and one of the participants in Guðjónsdóttir's study has met hostility when being misrecognized as a Pole $[s i c]$, while experiencing friendliness when people discover he is Icelandic (ibid.). The self-constructing practices described by Guðjónsdóttir are also described for Polish migrants in Great Britain, who emphasize their skin colour rather than their ethnicity as a means to bridge the gap between themselves and the host community. 'In contrast to ethnicity, which carries the danger of being associated with Poles from the wrong social class, an emphasis on race assumes membership within the dominant white English group, which also occupies higher social class positions' (Eade, Drinkwater and Garapich 2007: 18). Studies like these highlight the complex nature and entanglement of concepts like 'class' and 'race' (Rosa and Flores 2017) and how 
the specific socio-historical situations must be taken into account, especially within migrant contexts. Leinonen and Toivanen (2014) emphasize that 'race' alone does not explain why certain groups are more in/visible than others are. In/visibility can also be understood in connection to claiming recognition in society (2014: 164). The concept 'in/visibility' has turned out to be useful in a wider, yet more specific reference in this study, and is henceforth referring to visibility in public space through language use (cf. Leinonen 2012), where multilingualism in itself is partly understood as the presence of certain linguistic features associated with different 'languages' in public space.

Participation in working life and good knowledge of Norwegian are mentioned as key principles for inclusion in Norwegian society (Ministry of Culture 2020: 53). One could imagine that the invisibility in public space, as for instance the lack of explicit mentioning of nationality in NRK broadcastings, is an indicator of 'successful integration' (Slåke 2018). Previous research shows, however, that the lack of Norwegian language competence of Polish immigrants hinders integration in the workplace and more generally in society (Friberg 2012; Iglicka, Gmaj and Wierzejski 2016; Kraft 2017). Hence, the question of the relationship between multilingualism, visibility in public space and empowerment of individuals deserves closer inspection, as we now turn to the methodological and empirical parts of the chapter.

\section{Methodology and data}

Until quite recently, the concepts of place and belonging have been underdeveloped theoretically within sociolinguistic research. A growing body of both empirical and theoretical studies concerning place and space have emerged, based on the conceptualization of place as socially constructed (Cornips and de Rooj 2018: 2). Places are invested with sociocultural meaning through language practices (Quist 2018). Hence, place-making involves 'the assigning - through interaction - of social meaning to (physical) space(s), thereby creating places that are perceived as the basis of belonging' (Cornips and de Rooj 2018: 8). A research tradition that has been concerned with investigating how places are invested with sociocultural meaning through language practices is LL research. Critical LL studies involve the recognition of linguistic facts as strongly connected to general social facts (Ben-Rafael, Shohamy and Barni 2010: xiv). This chapter is influenced by LL research in its 'extended form' (e.g. Shohamy and Gorter 2009). A recognition of LL as social arenas, and the inclusion of people, both as interpretative subjects and agents, has emerged over time (Spolsky 2009: 31; Barni and Bagna 2015: 7). This study is qualitative in nature and recognizes the role of the interpretative subject as an essential part in the search for deeper understanding of the role of multilingualism in public space. Qualitative analyses are conducted to uncover the reasons for the appearance/disappearance of a brand or a sign in a given language, or to explain/describe how groups of speakers react in the face of restrictive regulations concerning the visibility of some languages in a territory' (Barni and Bagna 2015: 12). Speakers use language to construct places and senses of belonging in their daily practices (Quist 2018: 264), a point also mentioned by Stjernholm (2013) in her LL study from Oslo. Knowledge of the language practices 
perceived as legitimate when places are invested with sociocultural meaning is thus important for empowering individuals within a given sociohistorical context (cf. Kerfoot and Hyltenstam 2017).

The present study recognizes both visual and audible linguistic expressions as relevant semiotic resources in the investment of sociocultural meaning to public spaces. A (public) place is shaped and influenced by both audible and visual expressions, and the place itself influences these practices. An illustrative example of this connection is found in the notes from one of the participants in the study (Table 5.1, co-observer $1,11.15 \mathrm{am})$. She reports on how her wearing a name tag on a professional work assignment made strangers approach her in Polish, and how they accordingly were engaged in longer conversations. The visual sign, the name tag connoting 'Polish-ness' (Edelman 2009), generated a space for Polish language practice, adding to the overall impression of a multilingual space, or more precisely, a meaningful multilingual place. Blommaert and Maly (2014) include a sign on the back of a van with a Polish license plate in their ethnographically oriented LL study, arguing that attention to such nonpermanent, temporary or even accidental signs 'generates sensitivity to rapid and unpredictable social and cultural change' (2014: 7). The presence of non-permanent linguistic expressions should be included in a description of space and place-making building on the conceptualization of place as socially constructed. Hence, the data collection build on a rather wide conception of 'the patterns of social interaction in which people engage in the particular space' (Blommaert and Maly 2014: 3).

The empirical basis of the study is a combination of three periods of field observations. The first is the author's observations from regular walks through Oslo's inner city over a four-month period during spring 2018, and an additional period during winter/spring 2019. The third more systematic field observation took place on what will be referred to as the 'focus-day', a mid-week working day during spring 2018, with no prior or ongoing public holidays, special events or shattering news bulletins, neither in Poland nor in Norway. This was an attempt to capture 'just another everyday'. To support and adjust my own observations, two women assisted me with their own, separate field observations during the same day. They were simply asked to notice, and make short notes, every time they saw or heard Polish from the moment they entered public space in the morning, to the moment they returned to their respective private spaces in the afternoon.

Unlike myself, with only sparse competence in Polish, my co-observers were fluent in both Polish and Norwegian. They were chosen primarily because of their Polish language competence. However, an incautious selection of areas for observation may lead to biased and misleading results (Spolsky 2009: 32). In an attempt to yield a more holistic observation of a defined urban space, the co-observers were chosen because their point of view resembled my own in many respects. We were of the same age, more or less the same educational level, had similar places of residence in twoperson households and we all shared a workplace (often) requiring travelling through the similar parts of the inner city. The participants were guaranteed full anonymity throughout the process, and in accordance with relevant research-ethical guidelines (NSD 2018), no further identifiable aspects of their participation or contributions are 
Table 5.1. Reported Focus-Day Observations

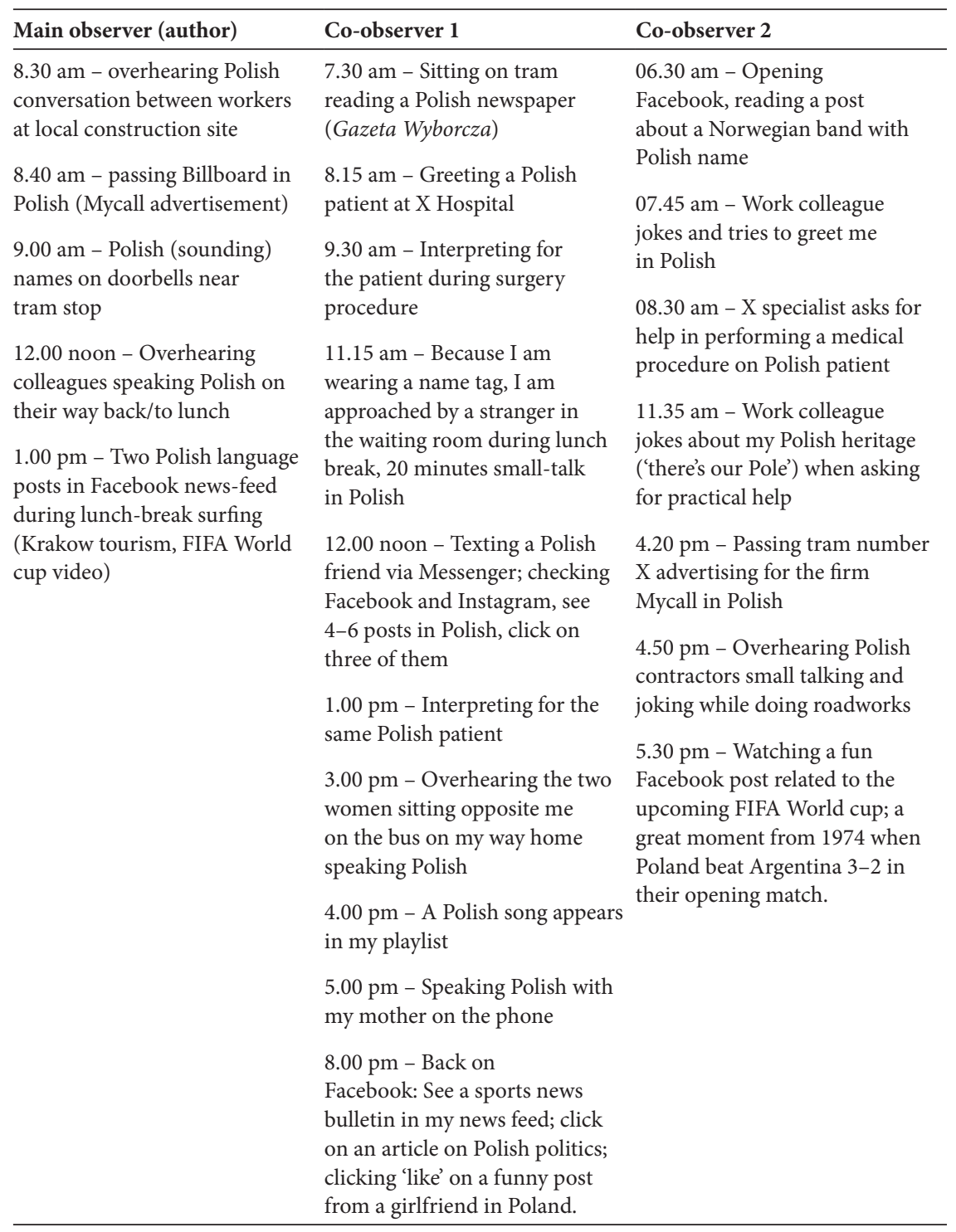


thus revealed in the following, and third-party information and names are given as ' $\mathrm{X}$ '. Table 5.1 offers an overview of our reported observations during the focus day. I have chosen to exclude from the present analysis the observations of Polish names on doorbells (Main observer), since these often represent the border between public and private spaces. Even though people's names may serve as contextualization cues and trigger interesting code switches, as was the case in the encounter triggered by the name tag described earlier, as well as generate interesting insights into multilingual language practices (Edelman 2009; Quist 2018), the onomastic dimension will remain a task for future research.

As can be seen from Table 5.1, the co-observers have conscientiously provided detailed accounts of their answers to 'whenever you see or hear polish during the day'. Hence, the reports also involve observations and participation in language practices that can hardly be associated with the public domain, no matter how liberal one's interpretation of 'public' is. Reports like 'at home talking Polish with my mother on the phone' and 'a Polish song appears in my playlist' (Co-observer 2, assuming she was wearing a headset if listening in public) are excluded from the analysis. At the same time, they are an important reminder of how the relationship between visibility and vitality is not a one-to-one relationship. Both co-observer 1 and 2 are involved in several language practices including Polish during this 'everyday' encounter. The main observer's strikingly shorter list of observations is not in itself striking, since my Polish competence differs significantly from the other observers' competence. There are nevertheless similarities and patterns worth noticing across the observations reported in Table 5.1. These are analysed as falling into four categories, presented further in the next section: the language-skill-based professional site, the construction site, the (billboard) campaign site and the virtual LL site. Based on the nature of the data collection and previous research, I have reason to believe that at least two additional sites are relevant for the presence of Polish in Norwegian public places, that is, the religious site and the educational site. These will be touched briefly upon after a closer look at the main categories that emerge from the data.

\section{Analysis}

\subsection{Categories of Polish presence}

\section{The language-skill-based professional site}

One category emerging from the observations made during the focus-day is the visible and audible instances of Polish as a form of linguistic capital - in Bourdieu's (1991) sense - in professional settings. My co-observers reported on how their language skills in Polish were recognized and included in problem-solving and professional development in their respective workplaces (e.g. co-observer 2, $8.30 \mathrm{pm}$, 'X specialist asks for help in performing a medical procedure on Polish patient'). Contrary to the observations and descriptions from blue-collar workplaces (see next section), their 
Polish language skill is treated as an additional and positive factor on top of and/or intertwined with their professional skills. The co-observers contribute in translation practices as well as the provision of professional networks, and their Polish background is in several ways recognized as a welcoming addition to the work community. This is especially evident in the report from co-observer 1, whose reports on the focus-day reveal her part-time profession as an interpreter. These observations support Obojska's (2018) findings, where young girls express a strong belief in that their knowledge of Polish will give them better chances on future job markets. In this respect, their individual multilingualism empowers them in their potential for professional success.

There is ambivalence at play here, though, in that certain language skills are recognized in parts of the labour market, while perceived as a drawback in others (Kraft 2017). Moreover, the valorized language practices invoke a kind of multilingualism that relies on an individual's ability to code shift between linguistic features associated with different national languages (i.e. 'Polish' and 'Norwegian') in specialized and professional settings. Both co-observers report on such practices, and I include the language-skill-based professional site as a relevant category for the presence of Polish in Norwegian public spaces.

\section{The construction site}

My initial observations leading up to - and following - the focus-day contained several instances of Polish presence on construction and renovating sites. Polish was obtained through eavesdropping into conversations between workers, but also through the observation of visual signs, such as the one presented as Figure 5.1. The sign reads 'Close the gate after you' in Norwegian and Polish, hand-written on a robust piece of wood bolted to the fence. The Norwegian version is on top, but the languages are of similar size and content, right down to the inclusion of a smiley. The observations made during the focus-day strengthen the impression of a strong tie between construction workers and Polish language practices. Two of the participants (Table 5.1, main observer at $8.30 \mathrm{am}$ and co-observer 2 at $4.50 \mathrm{pm}$ ) notice the presence of Polish at two different construction sites. I myself was only able to register the language practice as 'Polish', whereas my co-observer reported on 'Polish blue-collar workers throwing jokes at each other during work'.

The Polish immigration group consists of a myriad of professions (Iglicka, Gmaj and Wierzejski 2016), but since the 2004 EU enlargement, Poles are primarily associated with and often stereotyped as blue-collar labour migrants (Baba and Dahl-Jørgensen 2010). The stereotype, and to some extent stigmatization, of the Pole as a more or less uneducated, hard-working man with strong work ethics and limited language competence is also evident in media texts (Golden and Opsahl 2019). In the autumn 2014, the NRK released the television drama series Kampen for tilvorelsen (The struggle of existence), portraying the Polish linguist Tomasz Novak in search of his father. Novak's intellectual background is erased at almost every encounter with Norwegians, who automatically place him as an unskilled, poor construction worker (who at one point is offered a banana because they presume he is hungry). The series ignited a public debate, also involving the Polish ambassador to Norway, criticizing the use of 


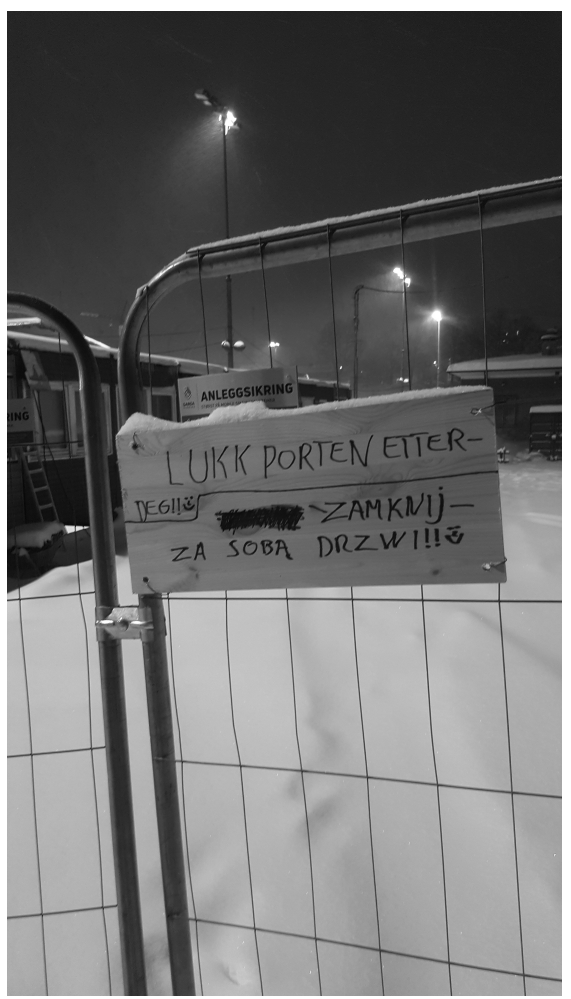

Figure 5.1 Sign at construction site. 'Close the gate after you' in Norwegian and Polish

outdated stereotypes (Czmur 2014). Regardless of critical voices, the construction sites still seem to be relevant as a category of Polish presence in Norwegian public spaces (Kraft 2017), and such a connection is present in my data set as well.

According to Friberg (2012: 1919), the vision of Poles as particularly hard-working seems to be a widely held notion, and the superior 'work ethic' of Polish labour migrants is a recurrent theme in Norwegian public debate (ibid.), creating a division between 'Polish jobs and 'Norwegian jobs'. Consequently, work organizations in the construction industry is often separated along lines of language and nationality (Friberg 2012: 1926; Kraft 2017). Friberg (2012) shows a pattern where Polish construction workers only work alongside other Poles and speak Polish only. Both the main observer and co-observer 2 report on Polish language use isolated from other languages. This pattern, which in fact does not render multilingualism, is ambivalent when it comes to the question of empowerment. Friberg (2012) shows how the capital associated with Polish workers' reputation for being particularly hard-working and compliant is available to all Polish workers, irrespective of their individual abilities 'Even the feeblest, laziest worker can benefit from this reputation as long as he appears to be Polish' (2012: 1929). Hence, being Polish is a valuable asset in the Norwegian 
construction industry, and displaying 'Polishness' through monolingual language practice may be used strategically to signal their competitiveness on the labour market. Where multilingualism involving Norwegian and Polish contributed to empowerment in the previous section, monolingual practices seems to be of essence in this case. The strong, migrant blue-collar-worker stereotype is also indirectly present in the next category: the billboard campaign site.

\section{The billboard campaign site}

Two of the participating observers point to an advertisement for a telephone company during the focus-day. Co-observer 2 mentions an advertisement on the tram, written in Polish, and the main observer points to a billboard written in Polish (see Figure 5.2). At first sight, the billboard makes little sense for people expecting the languages that dominated the same advertising spaces earlier during spring, that is, Norwegian and English. Paratexts, logos and pictograms point in the direction of a mobile telephone company, however, so the curious passer-by with no competence in Polish may still understand at least who the sender is. The billboard, reading Bliżej Polski (Close(r)

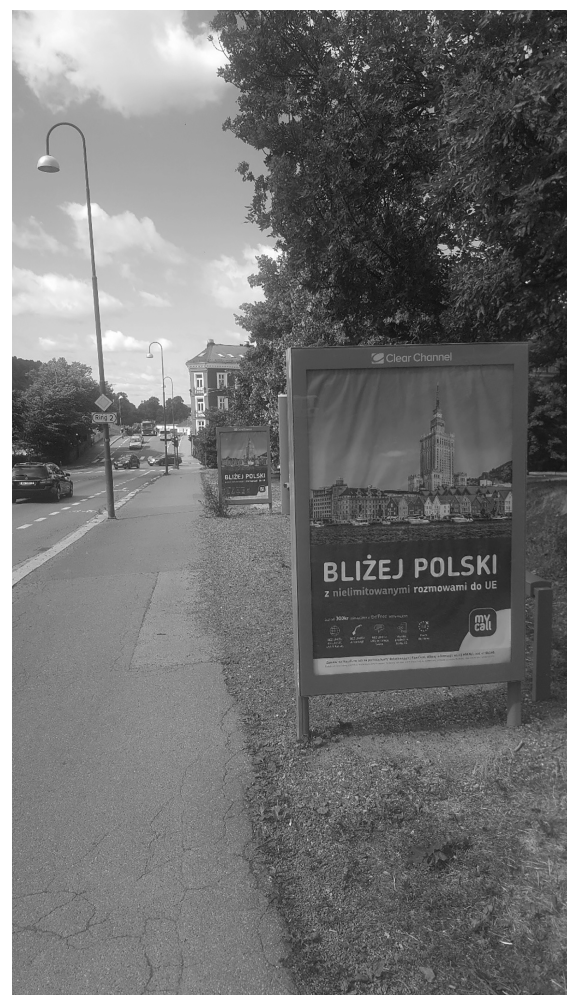

Figure 5.2 Billboard campaign, 'Closer to Poland' 
to Poland), is an advertisement for a mobile telephone company specializing in affordable and even free calls from Norway to recipients abroad. The billboard is part of a larger campaign advertising free calls to the EU under the slogan 'Closer to home'. Throughout the campaign, iconic Norwegian urban landmarks - such as for instance the Oslo Opera House or the modern architecture typical of the Oslo harbour area - are combined with parallel landmarks and cityscapes from the respective target countries.

The photograph of the iconic Palace of Culture and Science in Warsaw, originally dedicated to Stalin, may invoke Polish associations among observers without Polish language skills. For Poles, the building brings immediate connotations to Warsaw and Poland. The incorporation into the Norwegian cityscape is done both by the placement of the billboards themselves in the urban landscape, as well as through the aforementioned urban landmarks depicted. What is especially interesting in this billboard is that the iconic Norwegian landmark depicted is not in Oslo. The foreground of the Warsaw palace is in fact Bryggen (the Hanseatic dock), a UNESCO cultural heritage site in Norway's second-largest urban centre, Bergen. The Bryggen image seems to have been further manipulated through an adjustment of the waterline, floating seamlessly into the blue frame colour associated with the company's logo.

Mycall, the company behind the billboard, has received attention, as well as a 'bridge builder' award (Haugen 2013), for their inclusive company policies towards minorities and multilingualism. Their company web page offers three language choices: Norwegian, English or Polish, with rich opportunities to communicate with customer services in Polish. On their Facebook profile, the majority of their posts seems to be in Polish, although English and Norwegian as well as other languages are present. Their use of languages other than Norwegian or English, and especially Polish, seems to be treated as an unmarked choice in their social media appearance, especially on Facebook. The same may be said about their placing Polish billboards across central Oslo.

According to Spolsky (2009), the mixture of languages in advertisement is a result of growing globalization, and a situation where other languages are more likely to be understood, 'and even if not understood, to carry symbolic associations that can be exploited by the sign-maker' (Spolsky 2009: 36). The campaign and the billboard represent a clear example of the inclusion of Polish language as a relevant semiotic resource for public communication in Oslo. While signalling inclusion, ambivalence is also present: the clear incentives of the opportunity of being 'closer to Poland' and calling 'home' signal exclusion, since 'home' logically must be elsewhere. The tension regarding the status and whereabouts of 'home' is reinforced by the integration of a Polish national monument in the Norwegian cityscape, and at the same time widening the scope from the local place, Oslo, to the national context by involving the Norwegian city of Bergen. At one level, the billboard hence illustrates (stereotypical) notions of global migrant experiences more than local inclusion of multiple language practices.

The choice by a company with clear commercial interests to single out Poles as a target group is interesting. Poles' market value is recognized, so to speak. This speaks to the empowerment of individuals, in securing their ability to engage in customized commercial business. At the same time, the connotations of calling home emphasize 
the status of Poles as 'visitors', feeding the stereotypical image of the (temporary) work migrant. In this light, it is not clear that the symbolic associations carried by the billboard is exploited in an attempt of including customers with various language backgrounds, as Spolsky (2009) suggests for advertising in a globalized world. Rather, the group size is relevant for targeted advertising. Nevertheless, the data from the focus-day as well as other observations point to advertisement as a clear presence of Polish in Norwegian public spaces. The relationship between the multilingualism represented by the billboard campaign site is ambivalent in terms of the question of empowerment, however, a point to which we will return in the discussion section.

\section{The virtual Linguistic Landscape}

An in-depth analysis of the role of social media, and a broader digital diaspora, goes way beyond the limits of this chapter. However, all the observers mention social media as examples of the presence of Polish during the focus-day (also when leaving aside the reports on private communication via Messenger mentioned earlier). They all point to publicly shared Facebook posts, including humorous videos, news bulletins and historical sporting events (due to the then upcoming FIFA World Cup). The importance of including this category as an example of the presence of Polish is evident when taking the question of the empowerment of individuals into account. Obojska (2017) shows how digital practices are important for young Polish girls' identity construction and stance-taking, and further how social media can serve as a site where the members of diasporic communities and the members of the homeland societies come into contact and interact with each other. The reports from the two co-observers fit such a description, where Polish is used in phatic communication with close relatives and friends. Facebook contains shared news and clips that often go viral at a speed and in a manner that makes them present in the minds of large populations at the same time, sharing the same space for (transnational) language practices. Each person accesses a tailored and personal version of Facebook feed and adds. Hence, it is not straightforward to categorize this as a public shared experience. However, some posts are public and accessible to anyone (even those without an account), and these are included as an example of public space. The Polish presence is manifested also on my own Facebook wall (Table 5.1, Main observer $1.00 \mathrm{pm}$ ) and is hence not restricted to members of the diasporic community. Another example of Polish presence in virtual LLs is already touched upon, and that is the language choice-options on websites. Langue choice buttons may be considered important for empowerment, both in their recognition and visualization of multilingualism (Berezkina 2017), and in their creating the opportunity for the individual to engage in their language(s) of choice.

I have only access to the reported social media interactions, and no documentation of the interactions themselves (except for my own, which included a short video of a sporting event and a tourism advertising post shared by a Polish friend). One observation worth mentioning is how the linguistic practices I observed on Facebook seem to be free of any signs of code mixing. The use of Polish, English and Norwegian are typically kept strictly apart. This is a point also made by Obojska (2017). 


\section{The missing fifth and sixth site}

A potential site for Polish presence in Norwegian public places is the religious site. An indication of the relevance of looking into religious sites is the list of Catholic masses held in St. Olav's cathedral in Oslo's city centre. Polish is the second-most frequent choice of language for the saying of masses during the week, after Norwegian and before English and Vietnamese. The website katolsk.no, the official portal for Catholics in Norway, has an information banner in Polish on its front page (contributing to the point made above, of including the virtual LL in the overall picture of the presence of Polish). Polish seems to play a fundamental role in the Catholic congregations in Oslo, but the observers mention no such practices on the focus-day.

As mentioned earlier, the three observers were all members of two-person households. This is an important point, because none of us was likely to notice Polish in schools and/or children's culture and practices, which may represent a site for Polish presence. There exist some reports on the use of parallel language signing in public schools (Bygdås 2016), but as was mentioned in the introduction, a notion of invisibility is mentioned by educational researchers. The Norwegian school has long been regarded as an important factor in reducing social differences through an ideology of 'the unitarity school' (e.g. Telhaug 1994). Norwegian egalitarianism may be one possible explanation for the invisibility of the Polish children's immigrant status, Wærdahl (2016) suggests, pointing to the attempt to focus on similarities and create 'sameness' as 'another way of containing diversity and maintaining the egalitarian Norwegian self-image' (104). Based on the existing research (e.g. Bygdås 2016; Slany and Struzik 2016; Wærdahl 2016) it is safe to suggest that also the schoolscape contains an element of ambivalence regarding the presence of Polish. Neither the reports from the focus-day observations nor the other observations in the data set can complement this picture, so this remains as an important task for future research.

\section{Summary of findings}

Polish is not invisible in Norwegian public spaces. The observations have revealed that Polish is present both at construction sites and in other professional contexts. An advertising campaign in Polish was observed twice during the focus-day. In addition, Polish seems to have a strong presence in semi-public language practices on social media sites such as Facebook. Relative to the size of the population, the presence still must be considered limited. A year has passed since the focus-day presented above. When asking my co-observers today whether they are of the impression that things have changed since then, one of them responds as follows (translated from Norwegian): 'There is Polish everywhere: Collective transport, shops (my local bakery probably only employs Poles!), at work, and so on and so forth. And right now, as we speak, I am watching CNN, listening to President Duda speaking Polish.' The other co-observer agrees and points to even more translation assignments, more PolishNorwegian romantic couples among her acquaintances, more Polish films in cinemas. 
She also points to how Polish tourist destinations become increasingly popular, creating a stronger link between Norway and Poland. Without going so far as to claim that 'there is Polish everywhere', I myself have observed several additional examples of Polish presence in public space. The first restaurant in Oslo serving Polish specialties, U'mamy, has been established. The National Theatre's production of a play based on Wisława Szymborska's poems was presented with Polish subtitles and framed with texts in Polish, both on the theatre's website and social media sites (Nationaltheatret 2018). Additional Mycall-campaigns have regularly appeared during the year, on billboards, trams and metro stations, and Polish has appeared - alongside other migrant languages - in a billboard campaign for milk cartons from one of the largest dairy producers in Norway. An airport transportation company uses vehicles covered with Polish information, and so on and so forth. Some of these instantiations of Polish in Norwegian public spaces may have been present during the time of the collection of the data presented above and overlooked because of the limitations associated with the design of the field observations. At the same time, my co-observers seem to share my own feeling of an increased presence of Polish.

At least two important points emerge from the cases, where Polish appears as especially visible in the data set from the focus-day, and should be brought into the discussion, since they both relate to the question of empowerment. These points are interrelated and regards the question of multilingualism and the question of stereotypes and available identities. The 'Closer to Poland' billboard campaign and the construction sites, add - to some extent - to a stereotypical image of the (blue-collar) visiting working migrant more than representing an integral part of the local public space. The data create an impression of Polish identities existing parallel to, rather than integrated into, the Norwegian shared public space. Building on the theoretical assumptions presented earlier, one may claim that despite the presence of Polish in public spaces, there are few examples of Polish-Norwegian multilingual public places. The billboard, although playing with a level of polyphonic presence of other languages used in the wider campaign, was solely in Polish. The observations of Polish at the construction sites on the focus-day were of Polish with no other languages visible or audible. The observations of the recognition of Polish in professional lives were connected to instances of complete code shifts. Hence, Polish language seems to exist parallel to, and to a lesser degree close to or intertwined with, Norwegian (and other languages) in public spaces. We have also seen traces of ambivalence between the presence of Polish in public space and the maintenance of multilingualism, which should be discussed further. One of the research questions was whether multilingualism is protective of distinctive cultural identities or erodes them. This seems to be a highly relevant question in the Polish-Norwegian context, where the agency of some individual citizens seems to be restricted by strong expectations based on stereotypes directly linked to success at the job market. 


\section{Discussion}

\subsection{Mutually reinforcing ideologies}

The relationship between multilingualism and empowerment of individuals calls for an investigation of dominant language ideologies. Whereas Norway often has been highlighted as a sociolinguistic 'paradise' (Røyneland 2009), with rich socio-geographic variation and great tolerance towards linguistic diversity, Polish dialects are perceived almost exclusively negatively, and are associated with low education levels and social status (Garbacz 2014). Poland is traditionally seen as a country with a strong standard ideology, where language practices are directly related to ethnic belonging and national identity (Garbacz 2014; Obojska 2018). Different language policies are arguably governing the presence of different languages in the public space (e.g. Blackwood and Tufi 2012). Quist (2018: 241) points to how it is deeply rooted in European ideology to think of speakers and their languages as symbolically linked to cultures and places: 'It is embedded in the ways we speak about language, speakers and places: People in the place named Denmark are called Danes and their language Danish, symbolically indicating an internal coherence between them. However, the connection between people, places and languages can easily be deconstructed, claims, pointing to the fact that people are involved in practices involving several national 'languages', and that 'national languages' are widely in use outside of the respective nation states.

The supposed Norwegian openness towards linguistic diversity does not seem to include (all forms of) hybrid linguistic practices, or practices associated with another 'nation language', and resistance against Polish-Norwegian language practices is reinforced by dominant Polish ideologies. The connection between national and linguistic identity seems to be kept very much alive among Poles in Norway. Obojska (2017) portrays how young Polish girls tend to respond negatively to the use of Norwegian in Polish in-group settings, for instance online, where the choice of Norwegian connotes 'people lacking pride and respect for their origins and essentially lacking in "Polishness"' (Obojska 2017: 36). Young girls plan to transfer the Polish language to their future children out of a strong sense of obligation towards the mother tongue, responsive to a one nation-one language ideology, and they call on Polish national discourses to motivate their current and future language choices (Obojska 2018: 88; Obojska and Purkarthofer 2018: 259). According to Leinonen and Toivanen (2014: 163), the way the Nordic nations imagine themselves relies on ideas of cultural, religious and - to a certain extent - linguistic homogeneity. Associations between language and identity are rooted in cultural beliefs and values - that is, ideologies - 'about the sorts of speakers who (can or should) produce particular sorts of language' (Bucholtz and Hall 2010: 2). The ideological views associated with homogeneity are in line with a drift towards the attempt to focus on similarities and create 'sameness' to maintain an egalitarian self-image, as suggested for the 'invisible' status of Polish children in schools (Wærdahl 2016: 104). Monolingual and to some extent purist ideologies are at play in the Norwegian linguistic community (Mæhlum 2011). Conformity to linguistic practices associated with the community is often 
preferred. Bi-dialectal speakers, for instance, are shown to deliberately flee the risk of being spotted as dialect speakers in the 'wrong' contexts, hence turning to a sort of invisibility strategy (van Ommeren 2016).

A relatively strict separation of language practices associated with 'Polish' and 'Norwegian' (or other languages) is in other words in accordance with ideologies present in both societies. The strong connection between national and linguistic identity may serve as an explanatory factor for the somewhat limited and/or isolated character of the cases of Polish presence in the data, creating an image not so much of multilingualism as of the use of different languages in different settings. There may of course be methodological reasons for the few examples of multilingual presence, but the findings resonate well with previous research. In this light, the presence of Polish in Norwegian public spaces is creating an impression of a Polish space, alongside a Norwegian space, more than that of a multilingual place.

\subsection{Reinforcing stereotypes}

We have seen how the presence of Polish in public space feeds the stereotypical perception of the Polish blue-collar worker. Despite critical voices such as Czmur (2014), a strong stereotype connecting Poles and Polish to the performance of simple, manual labour at construction sites is still alive. This is most probably also connected to a gendered dimension. Most of the young boys in Obojska's studies (2018) had a history of exclusion or bullying at school, where they reported on being called names based on jobs associated with low-skilled 'immigrant' labour. A somewhat subtle example of a reinforcement of this stereotype is found in my data as well, in the reported observations from co-observer 2. At 11.35 am she reports how a 'work colleague jokes about my Polish heritage when asking for practical help'. The impression of Poles as being the ones 'getting things fixed' has also been evident in stereotypical and/or humorous portrayals in the media for two decades (Golden and Opsahl 2019; Slåke 2018).

Some researchers have pointed to patterns where the labour market seems unwilling to accept Poles' entry into other sectors of the labour force (Iglicka, Gmaj and Wierzejski 2016: 129). Moreover, temporary workers are largely selected based on the Polish stereotype, and stereotypes become a self-fulfilling prophecy, where 'workers act in a way that meets employers' expectations' (Iglicka, Gmaj and Wierzejski 2016: 123). Turning to the question of empowerment, and as addressed previously with reference to Friberg (2012), the situation remains ambivalent since Poles (are forced to) exploit the stereotypes in order to succeed in the labour market. As pointed to by Kraft (2017), these strategical moves only succeed to a certain point. There are jobs and tasks only available for the Norwegian-speaking part of the work force. Following Kraft (2017) we may say that it is language skills rather than professional skills that determine opportunities for the workers with Polish background. The process of acquiring specific multilingual linguistic skills may represent an asset for workers, as seemed to be the case for the co-observers providing data to the present study. Multilingualism also creates a restriction on professional opportunities for those who choose not to or are unable to engage in certain kinds of multilingual practices. Hence, some professional 
arenas, such as construction sites, in as far as they are observable for the public when travelling through the city, is an arena used to delegitimize specific (linguistic) groups. In this light, it is not surprising that some Polish migrants find it important to separate themselves from the Polish group identity, even when such practices may involve discursive hostility towards co-ethnics (Eade, Drinkwater and Garapich 2007: 16). This may be an additional explanatory factor as to the limited cases of Polish presence. Existing heterogeneity - as well as existing language differentiation - undergoes semiotic processes of erasure (Irvine and Gal 2000) causing one-dimensional prototypical identities, which in turn may render communicative challenges for the maintenance of multilingualism. This, in turn, could have a negative effect on other kinds of professions, where individual multilingualism is considered an asset. While the use of Polish adds to the impression of some degree of multilingualism in public space, which empowers individuals through their inclusion into the job market and to their financial security, there is a tension at play towards the maintenance of multilingualism. Not all forms of visibility are necessarily desirable, and certain languages can be reduced by being visible in less empowering ways. The opportunity or space available for negotiating contesting identities and create meaningful places of belonging seems narrow. Obojska (2018) suggests that stereotypes may affect the relationship of young Polish transnationals towards the heritage language and, 'in the long run, also influence the maintenance of Polish in diasporic communities' (Obojska 2018: 82).

\subsection{Market forces prevail}

Berezkina (2012) and Stjernholm (2013) point to customization and market logic as a reason for the under-representation of languages other than Norwegian and English in the urban LL of inner Oslo. Turning this around, the Polish presence - as demonstrated through the data - can be seen as an expression of language economy and potential profit (Cenoz and Gorter 2009; Duchêne and Heller 2012). The relative size and presence of Poles in Norway make them a suitable target for the construction of a niche market, which must be reached in certain languages and certain communicative styles (Heller and Duchêne 2012: 11). Polish is not necessarily acting as a source of symbolic added value, but literally as marketing authenticity opposite a Polish consumer identity. This was suggested for the billboard campaign site above, as an expression of clear commercial interests. Poles are singled out as a target group with a recognizable market value. The clearest examples of Polish presence in Norwegian public spaces are cases where - to borrow Heller and Duchêne's (2012) dichotomy - 'profit' rather than 'pride' is at stake. The visibility of Polish seems to depend on the language's market value. This value and commodity of the Polish language are to be understood not only symbolically but also economically.

The large group of people with Polish language competence make up a potential group of consumers and a niche market - for instance, for telephone companies and participants in institutional encounters, such as medical procedures in state hospitals, as illustrated in the focus-day data. The close relationship between Polish and renovation and construction sites can also be understood in light of an economic logic, since 
the strong stereotype maintains an expectation of 'getting the job done', that is, in an economically profitable way. Herein lays again an ambivalence of Polish presence. One may ask whether such stereotypes are typical for Polish migrants per se or whether it applies to groups of labourers from other countries. Friberg (2012: 1929) refers to the fact that many of his Polish respondents were aware that they were competing with other groups of workers in the Norwegian labour market: 'In order to maintain their position, they were dependent on their reputation, as Poles, for having a particularly strong work ethos' (ibid.). Still, it is not impossible that a slow yet evolving recognition of other qualifications is a factor, and that we may be facing a more multifaceted image of Poles in Norway in the near future. Examples of resistance towards the strong stereotype from professionals who have carved out alternative Polish-Norwegian identities exist. I witnessed one case of anecdotal evidence of this a few weeks ago. A colleague with Polish background shared a picture on Facebook, of a sign in Oslo, providing information for customers in Norwegian, English and Polish, side by side, in equally sized and shaped letters. His comment made it clear that this type of language practice in Norwegian public space was not something he embraced, as he read the inclusion of Polish as a signal of lover expectancy of linguistic competence among Poles. The presence of Polish was interpreted as a case of marginalization more than of empowerment. This case also points to how questions of empowerment can only be answered satisfactorily by including the individual, as interpretative subjects and agents, in the investigation of how public spaces transform into multilingual public places.

\section{Concluding remarks}

The multilingualism observed in this study, as well as in the previous research reviewed throughout the chapter, is in many ways protective of distinctive identities. Identities associated with the stereotypical professional lives of citizens with Polish backgrounds, and their role as consumers in global as well as local markets, are the most prominent traces of Polish in public spaces. The close connection between language and labour may at first glance be seen as a positive sign of empowerment of individuals. On the other hand, the agency of individuals in terms of their daily use of language is challenged when the presence of Polish in professional domains continue to feed and maintain stereotypical images of 'available' identities, depending not only on a symbolic value, but also on market economy.

The examples of Polish presence presented in this study add to an overall impression of Poles and Polish being a relevant market for economic exchange. The presence of Polish equals potential economic profit. At the same time, the increased amount of cultural expressions and encounters, such as the theatrical and gastronomical sites, and the reports of sporting, literary and musical expressions, point to a stronger sense also of 'pride' in addition to mere 'profit' (cf. Heller and Duchêne 2012). An increased symbolic added value to the presence of Polish may be underway. Space and places are in a way full-fledged 'speakers' in their own right (Gorter, Marten and Van Mensel 2011), and there is a good chance that public spaces in Norway continue to speak Polish 
in the future. A stronger presence of Polish in public spaces may potentially tear down some hindrances for the negotiation of alternative Polish-Norwegian identities. This, however, involves a risk of a stronger entanglement with Norwegian and a violation of dominant national language ideologies, seen from both a Norwegian and Polish perspective. The separation of language practices associated with 'Norwegian' and 'Polish' may seem necessary for maintaining social cohesion and the maintenance of dominant language ideologies. Seen from an individual's perspective, strong language ideologies of the one-nation-one-language kind may complicate opportunities for social mobility and well-being. Hence, the presence of Polish in Norwegian public space - in both visible, often domain-specific forms and more invisible forms - continue to raise important questions of integration and the empowerment of individuals.

\section{Note}

1. This work was partly supported by the Research Council of Norway through its Centres of Excellence funding scheme, project number 223265 and 302219. I wish to thank Luk Van Mensel, the reviewers and editors for invaluable input, and I am grateful to my co-observers, and to Anne Golden, Pawet $\mathrm{K}$. Urbanik and my other colleagues at MultiLing.

\section{References}

Aarsæther, F. (2010), 'The Use of Multiethnic Youth Language in Oslo', in P. Quist and B. A. Svendsen (eds), Multilingual Urban Scandinavia: New Linguistic Practices, 111-26, Clevedon, UK: Multilingual Matters.

Baba, M. L., and Dahl-Jørgensen, C. (2010), 'Work Migration from Poland to Norway: A New Institutional Approach', iNtergraph: Journal of Dialogic Anthropology, 2 (2).

Available online: http://intergraph-journal.net/enhanced/vol2issue2/2.html (accessed 29 July 2018).

Barni, M., and Bagna, C. (2015), 'The Critical Turn in LL: New Methodologies and New Items in LL', Linguistic Landscape, 1 (1-2): 6-18.

Ben-Rafael, E. (2009), 'A Sociological Approach to the Study of Linguistic Landscapes', in E. Shohamy and D. Gorter (eds), Linguistic Landscape: Expanding the Scenery, 40-54, New York: Routledge.

Ben-Rafael, E., Shohamy, E., and Barni, M. (2010), 'Introduction', in: E. Shohamy, E. Ben-Rafael and M. Barni (eds), Linguistic Landscape in the City, xi-xxviii, Clevedon, UK: Multilingual Matters.

Berezkina, M. (2012), 'Lingvistisk landskap i et av Oslos flerkulturelle områder', in T. Schmidt (ed.), Målblomar til Margit. Veneskrift til Margit Harsson på 70-årsdagen den 9. juni 2013, 19-34, Oslo: Novus.

Berezkina, M. (2017), 'Multilingual State Websites in Estonia and Norway. A Study of Language Policy in New Media', PhD diss., Department of Linguistics and Scandinavian Studies, University of Oslo, Oslo.

Berezkina, M. (2018), 'Language Is a Costly and Complicating Factor: A Diachronic Study of Language Policy in the Virtual Public Sector', Language Policy, 17 (1): 55-75. 
Berg, A.-J. (2008), 'Silence and Articulation - Whiteness, Racialization and Feminist Memory Work', Nordic Journal of Feminist and Gender Research, 16 (4): 213-27.

Bjorvatn, D. K. (2015), 'Slang i norsk. Forskningskampanjen 2014', MA diss., University of Oslo, Oslo.

Blackwood, R., and Tufi, S. (2012), 'Policies vs. Non-policies: Analysing Regional Languages and the National Standard in the Linguistic Landscape of French and Italian Mediterranean Cities', in D. Gorter, H. Marten and L. Van Mensel (eds), Minority Languages in the Linguistic Landscape, 109-26, Basingstoke: Palgrave Macmillan.

Blommaert, J., and Maly, I. (2014), 'Ethnographic Linguistic Landscape Analysis and Social Change: A Case Study', Working Papers in Urban Language \& Literacies, WP133, London: King's College.

Bourdieu, P. (1991), Language and Symbolic Power. Cambridge: Polity Press.

Bucholtz, M., and Hall, K. (2010), 'Locating Identity in Language', in C. Llamas and D. Watt (eds), Language and Identities, 18-28, Edinburgh: Edinburgh University Press.

Bygdås, M. E. (2016), 'Fra Warszawa til Oslo: Språkvalg og identiteter hos polsk-norske ungdommer', MA diss., University of Oslo, Oslo.

Cenoz, J., and Gorter, D. (2009), 'Language Economy and Linguistic Landscape', in E. Shohamy and D. Gorter (eds), Linguistic Landscape. Expanding the Scenery, 55-69, New York: Routledge.

Cornips, L., and de Rooj, V. (2018), 'Introduction', in L. Cornips and V. de Rooj (eds), The Sociolinguistics of Place and Belonging. Perspectives from the Margins, Studies in Language and Society 45, 1-16, Amsterdam: John Benjamins.

Czmur, S. (2014), 'Basert på foreldede stereotypier om Polen', Aftenposten, 9 October. Available online: https://www.aftenposten.no/meninger/debatt/i/1kw3J/Basert-paforeldede-stereotypier-om-Polen (accessed 27 July 2018).

Duchêne, A., and Heller, M. (eds) (2012), Language in Late Capitalism. Pride and Profit. New York: Routledge.

Eade, P. J, Drinkwater, D. S., and Garapich, M. (2007), Class and Ethnicity - Polish Migrants in London. University of Surrey: Centre for Research on Nationalism, Ethnicity and Multiculturalism. Available online: https://www.surrey.ac.uk/cronem/ projects/polish/class_and_ethnicity_polish_migrant_workers_in_london.htm (accessed 27 July 2018).

Edelman, L. (2009), 'What's in a Name? Classification of Proper Names by Language', in E. Shohamy and D. Gorter (eds), Linguistic Landscape: Expanding the Scenery, 141-54. New York: Routledge.

Friberg, J. H. (2012), 'Culture at Work: Polish Migrants in the Ethnic Division Labour on Norwegian Construction Sites', Ethnic and Racial Studies, 35 (11): 1914-33.

Friberg, J. H., and Golden, A. (2014), 'Norges største innvandrergruppe: Historien om migrasjon fra Polen til Norge og om andrespråkskorpuset ASK', NOA. Norsk som andrespråk, z: 11-23.

Friberg, J. H., Dølvik, J. E., and Eldring, L. (2013), Arbeidsmigrasjon til Norge fra Øst- og Sentral-Europa. VAM Temanotat. Oslo: Research Council Norway.

Garbacz, P. (2014), 'Dialekter i Norge og Polen: forskjellig status?', NOA. Norsk som andrespråk, 30 (2): 24-39.

Godzimirski, J. M. (2011), 'Polsk diaspora og norsk utenrikspolitikk', Internasjonal Politikk, 69 (4): 617-43.

Golden, A., and Opsahl, T. (2019), 'Norsk er norsk og polsk er polsk - «and never the twain shall meet»?', Paper presented at the 14th conference on Nordic Languages as a Second Language, Copenhagen, 27-9 May 2019. 
Golden, A., and Tenfjord, K. (2014), 'Møte mellom polsk og norsk i Norge', NOA. Norsk som andrespråk, 30 (2): 5-9.

Golden, A., Jarvis S., and Tenfjord, K. (eds) (2017), Crosslinguistic Influence and Distinctive Patterns of Language Learning: Findings and Insights from a Learner Corpus. Bristol: Multilingual Matters.

Gorter, $\mathrm{D}_{\boldsymbol{R}}$ Marten, H. F., and Van Mensel, L. (eds) (2012), Minority Languages in the Linguistic Landscape. Basingstoke: Palgrave Macmillan.

Guðjónsdóttir, G. (2014), “"We Blend in with the Crowd but They Don't" - (In)visibility and Icelandic Migrants in Norway', Nordic Journal of Migration Research, 4 (4): 176-83.

Gullestad, M. (2002), 'Invisible Fences: Egalitarianism, Nationalism and Racism', Journal of the Royal Anthropological Institute, 8 (2): 45-63.

Haugen, V. (2013), 'Mycall vinner brobyggerpris'. Available online: https://www.tek.no/ artikler/mycall-vinner-brobyggerpris/135951 (accessed 29 July 2018).

Heller, M. (2010), 'The Commodification of Language', Annual Review of Anthropology, 39: 101-14.

Heller M., and Duchêne, A. (2012), 'Pride and Profit: Changing Discourses of Language, Capital and Nation-State', in A. Duchêne and M. Heller (eds), Language in Late Capitalism. Pride and Profit, 1-21, New York: Routledge.

Horbowicz, P. (2010), How to Be Norwegian in Talk? Polish-Norwegian Interethnic Conversation Analysis. Oslo: Novus Press.

Iglicka, K., Gmaj, K., and Wierzejski, A. (2016), 'The Poles in Norway: We Wanted Workers but People Arrived', Myśl Ekonomiczna i Polityczna, 1 (52): 116-38.

Irvine, J., and Gal, S. (2000), 'Language Ideology and Linguistic Differentiation', in P. V. Kroskrity (ed.), Regimes of Language: Ideologies, Polities, and Identities, 35-83, Santa Fe, NM: School of American Research Press.

Janik, M. (2017), 'Positive and Negative Transfer in the L2 Adjective Inflection of English-, German- and Polish-speaking learners of L2 Norwegian', in A. Golden, S. Jarvis and K. Tenfjord (eds), Crosslinguistic Influence and Distinctive Patterns of Language Learning: Findings and Insights from a Learner Corpus, 84-109, Bristol, UK: Multilingual Matters.

Kerfoot, C., and Hyltenstam, K. (2017), 'Introduction. Entanglement and Orders of Visibility', in Kerfoot, C. and K. Hyltenstam (eds), Entangled Discourses. South-North Orders of Visibility, 1-15, New York: Routledge.

Kraft, K. (2017), 'Constructing Migrant Workers: Multilingualism and Communication in the Transnational Construction Site', PhD diss., Department of Linguistics and Scandinavian Studies, University of Oslo, Oslo.

Landry, R., and Bourhis, R. Y. (1997), 'Linguistic Landscape and Ethnolinguistic Vitality: Study', Journal of Language and Social Psychology, 16 (1): 24-49.

Leinonen, J. (2012), 'Invisible Immigrants, Visible Expats? Americans in Finnish Discourses on Immigration and Internationalization', Nordic Journal of Migration Research, 2 (3): 213-23.

Leinonen, J., and Toivanen, M. (2014), 'Researching In/Visibility in the Nordic Context: Theoretical and Empirical Views', Nordic Journal of Migration Research, 4 (4): 161-67.

Ministry of Culture (2020), 'Prop. 108 L (2019 - 2020), Proposisjon til Stortinget (forslag Lov om Språk (Språklova) [The Language Law Proposition], Oslo: Ministry of Culture. 
Mæhlum, B. K. (1998), 'Talemålsendring. En presentasjon av prosjektet TEIN, Talemålsendring i Norge', RISS: magasin for studentar og tilsette ved Institutt for nordistikk og litteraturvitskap, Trondheim: Universitetet i Trondheim.

Mæhlum, B. K. (2011), 'Det “ureine” språket: forsøk på en kultursemiotisk egritenskapsteoretisk analyse', Maal og Minne, 1: 1-31.

Nationaltheatret [the Norwegian National Theatre] (2018), 'Życie - jedyny sposób'. Available online: https://www.nationaltheatret.no/forestillinger/livet-er-den-enestematen/ycie-jedyny-sposob (accessed 17 June 2019).

NSD Data Protection Official for Research (2018), 'Should I Notify NSD about My Project?'. Available online: http://www.nsd.uib.no/personvernombud/en/notify/index. html (accessed 29 July 2018).

Obojska, M. A. (2017), “'Are You so Ashamed to Come from Poland and to Speak Your Mother Tongue?" - Metalinguistic Talk, Identities and Language Ideologies in Teenagers' Interactions on ASKfm', Multilingual Margins, 4 (1): 27-39.

Obojska, M. A. (2018), 'Between Duty and Neglect: Language Ideologies and Stancetaking among Polish Adolescents in Norway', Lingua, 298: 82-97.

Obojska, M. A., and Purkarthofer, J. (2018), ' “And All of a Sudden, It Became My Rescue": Language and Agency in Transnational Families in Norway', International Journal of Multilingualism, 15 (3): 249-61.

Ommeren, R. van (2016), 'Den flerstemmige språkbrukeren: en sosiolingvistisk studie anorske bidialektale, $\mathrm{PhD}$ diss., University of Trondheim NTNU, Trondheim.

Opsahl, T. (2009), 'Wolla I Swear This Is Typical for the Conversational Style of Adolescents in Multiethnic Areas in Oslo', Nordic Journal of Linguistics, 32 (2): 221-44.

Opsahl, T, Garbacz, P., Golden, A. Svennevig, J. (eds) (2019), 'Second-Language Communication in Workplace Settings - the Case of Polish Migrants in Norway (NorPol)', project proposal presented to the Research council of Norway, University of Oslo, Department of Linguistics and Scandinavian studies. Available online: https:// prosjektbanken.forskningsradet.no/\#/project/NFR/302219 (accessed 29 May 2020).

Quist, P. (2018), 'Alternative Place Naming in the Diverse Margins of an Ideologically Mono-Lingual Society', in L. Cornips and V. de Rooj (eds), The Sociolinguistics of Place and Belonging. Perspectives from the margins, Studies in Language and Society 45, 239-58, Amsterdam: John Benjamins.

Rosa, J., and Flores, N. (2017), 'Unsettling Race and Language: Toward a Raciolinguistic Perspective', Language in Society, 46 (5): 621-47.

Røyneland, U. (2009), 'Dialects in Norway: Catching Up with the Rest of Europe?', International Journal of the Sociology of Language, 196 (7): 7-31.

Shohamy, E., and Gurter, D. (2009), 'Introduction', in E. Shohamy and D. Gurter (eds), Linguistic Landscape. Expanding the View, 1-10, New York: Routledge.

Schröter, M., and Taylor, C. (2018), 'Introduction', in M. Schröter and C. Taylor (eds), Exploring Silence and Absence in Discourse. Empirical Approaches, 1-22, Basingstoke: Palgrave Macmillan.

Slåke, A. L. (2018), 'Portraying a Major Minority in Televised Public Service Broadcasting. Portrayal of Polish Immigrants in the Norwegian Broadcasting Corporation', MA diss., Department of Information Science and Media Studies, University of Bergen, Bergen.

Slany, K., and Struzik, J. (eds) (2016), Doing Family in a Transnational Context. Demographic Choices, Welfare Adaptations, School Integration and Every-day Life of Polish Families Living in Polish-Norwegian Transnationality. Krakow: Jagiellonian University. 
Spolsky, B. (2009), 'Prolegomena to a Sociolinguistic Theory of Public Signage', in E. Shohamy and D. Gurter (eds), Linguistic Landscape. Expanding the View, 25-39, New York: Routledge.

SSB Statistics Norway (2019), 'Lower Growth in the Number of Immigrants', 5 March. Available online: https://www.ssb.no/en/befolkning/artikler-og-publikasjoner/lowergrowth-in-the-number-of-immigrants (accessed 19 July 2019).

Stjernholm, K. (2013), 'Stedet velger ikke lenger deg, du velger et sted. Tre artikler om språk i Oslo', PhD diss., Department of Linguistics and Scandinavian Studies, University of Oslo, Oslo.

Svendsen, B. A., and Røyneland, U. (2008), 'Multiethnolectal Facts and Functions in Oslo, Norway', International Journal of Bilingualism, 12 (1-2): 63-83.

Szymańska, O. (2017), 'On How Polish Learners of Norwegian Render Spatial Prepositions in L2: A Corpus-Based Study of $\mathrm{i}$ and på, in A. Golden, S. Jarvis and K. Tenfjord (eds), Crosslinguistic Influence and Distinctive Patterns of Language Learning: Findings and Insights from a Learner Corpus, 64-83, Bristol, UK: Multilingual Matters.

Telhaug, A. O. (1994), Utdanningspolitikken og enhetsskolen. Studier i 1990-årenes Utdanningspolitikk, Oslo: Didakta.

Thurlow, C., and Jaworski, A. (2010), 'Silence Is Golden: The "Anti-Communicational" Linguascaping of Super-Elite Mobility', in A. Jaworski and C. Thurlow (eds), Semiotic Landscapes: Language, Image, Space, 187-218, London: Continuum.

Urbanik, P. (2017), 'Requests in Polish and Norwegian Informal Conversation: A Comparative Study of Grammatical and Pragmatic Patterns', PhD diss., Department of Linguistics and Scandinavian Studies, University of Oslo, Oslo.

Urbanik, P. (2020), 'Getting Others to Share Goods in Polish and Norwegian: Material and Moral Anchors for Request Conventions', Intercultural Pragmatics, 17 (2): 177-220.

Wærdahl, R. (2016), 'The Invisible Immigrant Child in the Norwegian Classroom: Losing Sight of Polish Children's Immigrant Status through Unarticulated Differences and Behind Good Intentions', Central and Eastern European Migration Review, 5 (1): 93-108. 